\title{
ІНФОРМАЦІЙНІ ПРОБЛЕМИ ЗАБЕЗПЕЧЕННЯ НАСТУПНОСТІ МЕДИЧНОЇ ДОПОМОГИ
}

\author{
Національна медична академія післядипломної освіти імені П. $\Lambda$. Шупика
}

\begin{abstract}
Розглянуті проблеми забезпечення наступності та безперервності медичної допомоги. Проаналізовані інформаційні та кібернетичні питання наступності, зокрема інформаційні стандарти, системи управління ресурсами лікувальної установи. Підкреслюється думка про необхідність розроблення стандартів наступності медичноїдопомоги.
\end{abstract}

Ключові слова: наступність і безперервність медичноїдопомоги, доступність медичноїдопомоги, дефекти якості медичної допомоги, інформаційні стандарти наступності та безперервності медичної допомоги, системи планування й управління ресурсами.

\section{ИНФОРМАЦИОННЫЕ ПРОБЛЕМЫ ОБЕСПЕЧЕНИЯ ПРЕЕМСТВЕННОСТИ МЕДИЦИНСКОЙ ПОМОЩИ}

\author{
Н. В. Харик, Н. В. Банчук
}

\begin{abstract}
Национальная медицинская академия последипломного образования имени П. $\Lambda$. Шупика
\end{abstract}
Рассмотрены проблемы обеспечения преемственности и непрерывности медицинской помощи. Проанализированы информационные и кибернетические вопросы преемственности, в частности информационные стандарты, системы управления ресурсами лечебного учреждения. Подчеркивается мысль о необходимости разработки стандартов преемственности медицинской помощи.

Ключевые слова: преемственность и непрерывность медицинской помощи, доступность медицинской помощи, дефекты качества медицинской помощи, информационные стандарты преемственности и непрерывности медицинской помощи, системы планирования и управления ресурсами.

\section{INFORMATION SECURITY PROBLEMS OF SUCCESSION OF MEDICAL CARE}

\section{N. V. Kharyk, M. V. Banchuk \\ National Medical Academy of Post-Graduate Education named after P. L. Shupyk}

The problems of ensuring the succession and continuity of medical care were examined. The information and cyber matters of succession, in particular, information standards, resource management systems of medical institutions were analyzed. The idea of the need to develop standards for succession of medical care is emphasized.

Key words: succession and continuity of medical care, accessibility of health care, defects in quality of medical care, information standards of succession and continuity of medical care, planning and resource management systems.

Вступ. Питаннями забезпечення наступності та безперервності медичної допомоги останнім часом займалися численні дослідники [1, 3-6]. Зазвичай під цими термінами розуміється координація діяльності в процесі надання пацієнтові медичної допомоги в різний час, різними фахівцями та лікувальними установами. Наступність при наданні медичної допомоги значною мірою забезпечується стандартними вимогами до медичної документації [6], технічного оснащення, процесу та персоналу.

Передбачається, що така координація діяльності медпрацівників гарантує стабільність процесу ліку(C) Н. В. Харик, М. В. Банчук вання та його результату [9]. Проте насправді наступність медичної діяльності, як правило, не забезпечується. Передусім, поняття «координація» погано визначено. Воно не містить кількісних параметрів і сприймається різними авторами та більшістю медиків по-різному. Крім того, на наступність сильно впливають супутні чинники, наприклад, доступність медичної допомоги, лікарські помилки в діагностичних і лікувальних процедурах тощо.

Метою цієї роботи є формалізація визначень, процедур і висновків у проблемі наступності медичної допомоги. 
Постановка проблеми. Розумітимемо під наступністю таку послідовність дій лікарів, при якій досягається максимально можливе збільшення вірогідності сприятливого результату захворювання. В якості другого завдання розглядатимемо максимальне зменшення вірогідності ускладнень та інших негативних проявів патологічного процесу. Абсолютно очевидно, що досягнення наступності медичної допомоги можливе при виконанні інших умов.

Результати та їх обговорення.

Дослідження проблеми. Першим чинником, що сильно впливає на забезпечення наступності, $\epsilon$ доступність медичної допомоги.

1. Доступність медичної допомоги є найважливішою умовою надання медичної допомоги населенню в усіх країнах світу, що відображає як економічні можливості держави в цілому, так і можливості конкретної людини. На жаль, ніде не забезпечується загальний і рівний доступ до всіх видів медичних послуг. Виходом $з$ такої ситуації є скорочення витрат на неефективні види медичних втручань і концентрація зусиль на наданні рівного доступу до найефективніших медичних послуг. Подібний підхід до використання обмежених ресурсів називається раціонуванням і практикується різною мірою в усіх державах світу. У бідних країнах раціонування відкрите і повсюдне, зачіпає майже всі види медичної допомоги, в економічно багатих країнах воно зазвичай обмежене коштовними видами допомоги або окремими групами громадян. Крім того, у багатьох державах $€$ приховане раціонування: черги, через які неможливо отримати лікування в розумні терміни, виключення окремих видів лікування зі списку безкоштовних послуг тощо.

1.2. На забезпечення наступності медичної допомоги сильно впливають дефекти якості медичної допомоги. Згідно з даними міжнародної статистики, найбільш суттєвими причинами дефектів роботи лікарів є: недостатня кваліфікація медичних працівників, що трапляється в 24,7 \% випадків, неповноцінне обстеження пацієнтів - 14,7 \%, неуважне ставлення до хворого - 14,1 \%, недоліки в організації лікувального процесу - 13,8 \%, недооцінка тяжкості стану хворого - 2,6 \%.

Зазначимо, що за деякими даними, дефекти організації медичної допомоги складають не менше 20 \% усіх дефектів медичної допомоги. За даними Американської асоціації лікарів, щорічно в США з вини медичних працівників помирають понад 200 тис. чоловік [4]. Приблизно така ж кількість людей помирає від неправильного призначення або побічних дій лікарських засобів (ЛЗ).
Від 3 до 5 надходжень хворих у стаціонари викликано побічними ефектами лікарських засобів, що в десятки разів більше, ніж внаслідок помилок хірургів. У Росії, на думку експертів, кожен третій діагноз ставиться невірно [3, 9].

1.3. Безперервність медичної допомоги. Безперервність нагляду за пацієнтами є одним з основних чинників забезпечення наступності медичної допомоги.

Абсолютно очевидно, що контроль безперервності медичної допомоги повинен забезпечуватися інформаційними механізмами. У міжнародній практищі відповідний стандарт дістав назву CCR (Continuity of Care Record). CCR набір даних включає резюме пацієнта за станом здоров' я (наприклад, діагноз, ЛЗ, алергії) та основну інформацію про страхування, перелік попередніх розпоряджень, план лікування. Він також включає ідентифікуючу інформацію та мету CCR.

CCR може бути отриманий, відображений і переданий на папері або в електронному вигляді. При отриманні в структурованому електронному вигляді необхідно суворо дотримуватися схеми XML. Первинно в CCR надається моментальний знімок, що містить відповідні клінічні, демографічні й адміністративні дані для конкретного пацієнта. XML кодування забезпечує гнучкість, що дозволить користувачам підготовку, передачу і перегляд CCR декількома способами, наприклад, у браузері, як елемент Health Level 7(HL7) повідомлення або сумісний CDA документ, в захищеній електронній пошті, як PDFфайл, як HTML- файл, або в якості документу для оброблення текстів.

Природно, що має бути забезпечений захист даних. При цьому умови безпеки та конфіденційності для CCR мають бути встановлені таким чином, що дозволяє забезпечувати доступ до екземпляра документу CCR або його елементів тільки при правильній аутентифікації й авторизації.

1.4. Управління плануванням лікувального процесу. Останніми роками запропоновані декілька систем управління лікувальним процесом, що дозволяють оптимізувати діагностичні та лікувальні процедури. Розглянемо деякі з них.

Істинне призначення систем планування й управління ресурсами в лікувальній установі (ERP Enterprise Resource Planning) - автоматизація процедур, що утворюють лікувальний процес, і інтеграція всіх підрозділів установи в єдину систему, що зможе обслужити всі специфічні потреби у кожному конкретному випадку. ERP-системи особливо потрібні великим лікувальним закладам з розгалу- 
женою філіальною мережею і великим асортиментом послуг, що надаються.

В основі систем ERP лежить принцип створення єдиного сховища даних, що містить усю інформацію про пацієнта та забезпечує одночасний доступ до неї будь-якої необхідної кількості співробітників лікувальної установи, наділених відповідними повноваженнями. Основними функціями ERP є планування потреб в діагностичному обстеженні, Л3, термінів відвідування діагностичних процедур, управління запасами та закупівлями, планування потужностей, оперативне управління фінансами тощо.

ERP - комплексне рішення, що замінює старі розрізнені комп'ютерні системи з фінансів, управління персоналом, контролю над виробництвом, логістики однією уніфікованою системою, що складається 3 програмних модулів, які повторюють функціональність старих систем.

Системи підтримки прийняття рішень (DSS Decision Support Systems) є інформаційними системами, максимально пристосованими до вирішення завдань повсякденної управлінської діяльності й $€$ інструментом, що допомагає лікарям приймати обгрунтовані й ефективні управлінські рішення. DSS дозволяють в режимі реального часу автоматично аналізувати великі обсяги інформації. За допомогою

\section{Література}

1. Кирьянов К. Г. Выбор оптимальных базовых параметров источников экспериментальных данных при их идентификации // Труды III Международной конференции ЗГСРЯО / ИПУ РАН. - М., 2004. - С. 187-208.

2. Микони С. В. Теория и практика рационального выбора / С. В. Микони. - М. : Маршрут, 2004. - 463 с.

3. Оценка зарубежных систем здравоохранения: частные мнения и индекс потребителей медицинских услуг // Вопросы экономики и управления для руководителей здравоохранения. - 2008. - №> 2 (77). - С. 23-26.

4. Оценка качества здравоохранения США// Вопросы экспертизы и качества медицинской помощи. - 2008. - № 2 (26). - С. 61-64.

5. Северский А. В.Значение протоколов ведения больных в судебной практике / А. В. Северский, Е. О. Сергеева .// Про-
DSS можуть вирішуватися неструктуровані та слабоструктуровані багатокритерійні завдання. Інтерактивна автоматизована система допомагає особі, яка приймає рішення, використати дані та моделі для виявлення і рішення завдань та прийняття рішень.

Такі корпоративні системи працюють з інтерактивними запитами та формують звіти в режимі он-лайн. Мета DSS - підвищення ефективності рішень. Вони дозволяють ефективно працювати як із структурованою, так і з неструктурованою інформацією; аналізувати та співвідносити дані з зовнішніх і внутрішніх джерел. Сьогодні існує і безліч приватних рішень, наприклад, BSC (Balanced Scorecard) - збалансована система показників. Суть їі в тому, що спочатку формулюються стратегічні цілі лікування, потім кожна з цілей розпадається на дрібніші і так далі.

Висновки. 1. Забезпечення наступності та безперервності медичної допомоги тісно пов'язано 3 розробленням систем планування й управління ресурсами в лікувальній установі.

2. Ефективність процесів забезпечення наступності залежить від автоматизації процедур, що утворюють лікувальний процес, та інтеграції всіх підрозділів установи в єдину систему. Вкрай важливим є розроблення та впровадження в практику систем підтримки прийняття рішень.

блемы стандартизации в здравоохранении. - 2005. - №2 11. - C. 6-12.

6. Основные положения конщепщи стандартизащии медищинских услуг / Стародубов В. И., Воробьев П. А., Якимов О. С. [и др.] // Экономика здравоохранения. - 1997.- №2 10. - С. 5-10. 7. Усков А. А. Интеллектуальные технологии управления. Искусственные нейронные сети и нечеткая логика / А. А. Усков, А. В. Кузьмин. - М. : Горячая линия-Телеком, 2004. - $143 \mathrm{c}$.

8. Черноруцкий И. Г. Методы оптимизации в теории управления / И. Г. Черноруцкий. - СПб. : Питер, 2004. - 256 с. 9. Якубовяк В. Международный опыт стандартизации в здравоохранении / В. Якубовяк // Проблемы стандартизации в здравоохранении. - 2002. - №2 4. - С. 3-5. 